\title{
Eszterházy Károly egri püspök könyvtárának csillagászati könyvei*
}

A 18. század európai tudományos gondolkodásában a csillagászat már jelentős helyet foglalt el. A felvilágosodás szellemi áramlatának egyik fontos jellemvonásaként tekintünk arra, hogy a régi (középkori) gondolkodást felváltotta a „modern”, ami (erősen leegyszerüsítve) annyit jelent, hogy a természeti és társadalmi folyamatok értelmezésekor elutasított minden természetfölötti magyarázatot. Szabó Árpád (1913-2001), a neves klasszika-filológus az ókori tudományról szóló müvében azt írja: „A tudományban minden nemzedék ott folytatja, ahol a megelözo" abbahagyta a munkát. A tudomány (tehát) kumulativ jellegü. (...) Ismer azonban a tudománytörténet olyan forradalmi korszakokat is, amelyek lerombolják, szinte semmivé teszik a korábban sok fáradsággal, türelemmel fölépitett konstrukciót, hogy lerakják valami újnak, többet igérönek az alapjait." ${ }^{1}$ A kora újkor természettudományos forradalmi korszaka után, amelyet Kopernikusz, Galilei, Kepler és Newton életmüve fémjelez, nyugodtabb időszak következett: az adatgyüjtés, a felhalmozás (akkumuláció) kora, ami egyúttal a korábbi jelentős felismerések gyakorlati alkalmazását is jelentette. Ilyen korszak volt a természettudomány történetében a 18. század, ami a jelen tanulmány középpontjában álló Eszterházy Károly főpapi működésének is az időszaka.

Eszterházy maga is úgy vallotta, hogy századának magas színvonalú egyetemi képzéséhez szorosan hozzátartozik a csillagászat oktatása is. Pontosan látta a természettudományos kutatások előremutató jelentőségét, ezért és már a meglévő gyakorlatok hatására is - Leiden (1632), Koppenhága (1637), Párizs (1667), Magyarországon pedig először Nagyszombat (1753) - a tervezett egyetemében a csillagászat elméleti és gyakorlati oktatásának megteremtését is célul tüzte ki. Az egri csillagásztorony kivitelezése és müszereinek beszerzése mellett Eszterházy gondosan ügyelt a megfelelő szakkönyvek összegyüjtésére. A jelen írás elsősorban ennek a könyvgyüjteménynek az 1800 elötti anyagával kíván foglalkozni. Tesszük ezt egyfelől azért, mert még ma is kevés ismerettel rendelkezünk a kollekció összetételéről, és úgy gondoljuk, hogy egy lépéssel közelebb kerülhetünk e munkával az Eszterházy-féle püspöki könyvtár

\footnotetext{
* A tanulmány elkészítését támogatta az EFOP-3.6.1-16-2016-00001 „Kutatási kapacitások és szolgáltatások komplex fejlesztése az Eszterházy Károly Egyetemen” című pályázata.

1 Szabó Árpád-Kádár Zoltán: Antik természettudomány. Bp. 1984. 8-10.
} 
rekonstrukciójához. ${ }^{2}$ Ezzel együtt arra a kérdésre is keressük a választ, hogy a kor legjelentősebb csillagászati eredményeivel összevetve mennyire tekinthető teljesnek a vizsgált könyvgyüjteménynek a témánkhoz kapcsolódó része. A jelen írás mindeközben egy nagyobb lépékủ munkára is fel kívánja hívni a figyelmet: az egri Főegyházmegyei Könyvtár teljes csillagászati anyaga analitikus feltárásárának hiányára. Ugyan a könyvtár cédulakatalógusa elkészült már, de annak átfogó bemutatására mindeddig nem került sor. E témában az eddigi legteljesebb összefoglalást Kelényi B. Ottó (1897-1944) történész, bibliográfus munkája jelenti, amelyben nagy alapossággal, a korabeli forrásokra támaszkodva tekinti át az egri csillagvizsgáló torony történetét, valamint értékes információkat nyújt a csillagászati szakrészleg kialakulásának történetéről is. ${ }^{3}$ A gyüjtemény pontosabb megismerését segítették elő Surányi Imrének (1928-2018), az egri Főegyházmegyei Könyvtár egykori tudományos munkatársának a könyvtár egyes csillagászati kiadványairól szóló leírásai is. ${ }^{4} \mathrm{~A}$ munka azonban azóta sem folytatódott átfogóbb leírásokkal. A jelen dolgozat tehát e hosszabb léptékủ feltáró munkának egy állomása, amivel az Eszterházy-féle könyvgyűjtés hátterét (mind könyvtár-, mind tudománytörténeti oldalról) szeretnénk összegezni, valamint az 1800 előtti csillagászati kiadványok összetételét ismertetni.

Az egri Főegyházmegyei Könyvtár csillagászati könyveinek feltáró munkáját az egri Esterhazyanum Kutatócsoport két munkatársa (Csorba Erzsébet és Nagy Andor) kezdte el. E munkának a fizikai, csillagászati vonatkozású kérdéseiben szakmai útmutatást nyújtott Ujfaludi László, az Eszterházy Károly Egyetem Fizikai és Élelmiszerfizikai Tanszékének professzora is, aki a jelen tanulmányban a könyvek tudománytörténeti hátterére is rávilágít.

2 Legátfogóbban az Eszterházy-féle gyűjteményről lásd: Antalóczi Lajos: A kétszáz éves Egri Főegyházmegyei Könyvtár története (1793-1993). In: Kétszáz éves az Egri Főegyházmegyei Könyvtár 1793-1993. Emlékkönyv. Szerk. Antalóczi Lajos. Eger 1993. 29-37. Löffler Erzsébet: Az Egri Föegyházmegyei Könyvtár. Eger, Érseki vagyonkezelő Központ, 2012.; Löffler Erzsébet: Az Egri Főegyházmegyei Könyvtár. In: Az egri Domus Universitatis és Líceum. Oktatás, tudomány, művészet 1763-2013. Szerk. Petercsák Tivadar. Eger 2013. 116-120.

3 Kelényi B. Ottó: Eszterházy Károly gróf egri püspök csillagvizsgálójának könyvtára és az egri asztronómusok működése. Stella IV. 1-2. sz. 1930. 22-38. A csillagásztorony kialakulásának történetét lásd: Bevilaqua-Borsody Béla: A Galánthai Gróf Eszterházy Károly egri püspök által alapított egri egyetem csillagvizsgálójának története. 1762-1883. (Adalékok a 18-19. század magyar műveltségtörténetéhez.) Stella IV. évf. 3-4. sz. 1929. 101-143.; Kelényi B. Ottó: Az egri érseki Liceum csillagvizsgálójának története. A History of the Observatory of the Archiepiscopal College in Eger. Bp. 1930.; Petercsák Tivadar: Specula - Csillagászati Múzeum. In: Az egri Domus Universitatis és Líceum. Oktatás, tudomány, művészet 1763-2013. Szerk. Petercsák Tivadar. Eger 2013. 151-167.; Nagy Andor: Az égboltot kémlelők varázstornya. In: Eszterházy egyeteme. Az egri Líceum képes albuma. Szerk. Nagy Andor. Eger 2017. 78-101.

4 Surányi Imre: Csillagászati könyvritkaságok az egri Főegyházmegyei Könyvtárban. Eger 2004. (Kézirat EFK); Surányi Imre: Az Egri Főegyházmegyei Könyvtár könyvritkaságai. Válogatás 11-19. században megjelent kéziratos és nyomtatott művek közül. Eger 2009. 140-155. 
Dolgozatunk első részében az egri egyetemi képzés háttérintézményét jelentő föpapi könyvgyüjtemény bemutatására kerül sor, különös tekintettel a kötetek beszerzésének szempontjaira. Ezt követően pedig a könyvtár csillagászati gyűjteményének statisztikai szempontú elemzését kívánjuk adni, utalva a tudománytörténet nagy hatású műveinek meglétére vagy azok hiányára.

\section{Főpapi könyvgyưjtés a tudomány szolgálatában}

Eszterházy Károly a püspöki székét 1762 június 29-én foglalta el Egerben. A Rómában tanult, széles látókörrel rendelkező fópap ekkor fejlesztette tovább elődjének, Barkóczy Ferencnek (1710-1765) az egri egyetem alapítására vonatkozó elképzelését oly módon, hogy az egyetem épületében helyet kaphasson - egyebek mellett - egy könyvtár és egy csillagásztorony is. ${ }^{5} \mathrm{~A}$ püspök négyfakultásos egyetem alapítását tervezte teológiai, jogtudományi, bölcseleti és orvostudományi karokkal. A könyvtár elsősorban e tudományok oktatóit és hallgatóit volt hivatott kiszolgálni. Mint ismeretes, az egri universitas azonban nem kapta meg a bécsi udvar jóváhagyását, ettől függetlenül azonban a püspök élete végéig feltétel nélküli támogatásban részesítette a Líceumot és a hozzá tartozó bibliotékát.

Eszterházy Károly tudatos terv alapján alakította ki a könyvtár állományát, a gyűjtést a tervezett egyetemi karoknak megfelelő tudományokra irányítva. Eszterházy püspök könyvgyüjteményét részben külföldről beszerzett kiadványok, részben Magyarországon gyűjtött művek teszik ki. A hazai gyűjtés egyik csoportja a korábban létrejött, később pedig a püspökivel „egybeolvasztott” könyvtárak anyagai, például az egri kanonokok (Barta István (1719-1785), Ambrosovszky Mihály (1702-1792), Berecz Mihály, Major József, Csák István (?-1789 előtt), Keller János stb.) magánkönyvtárai vagy az egyházmegye plébánosainak (Kasper Péter, Almásy József, Kocher István, Fischer István és Tahy József stb. ${ }^{6}$ adományai és hagyatékai. A másik csoportba

5 A téma gazdag szakirodalommal rendelkezik, amelyeknek csupán a felsorolása is jelentős helyet igényelne. A legfrissebbek ezek közül: Bitskey István: Eger a barokk kori Közép-Európában. In: Az egri Domus Universitatis és Líceum. Oktatás, tudomány, művészet 1763-2013. Szerk. Petercsák Tivadar. Eger 2013. 13-39.; Mészáros István: Egyetemszervezési tervek Egerben 1754-1948. In: Acta Academiae Paedagogicae Agriensis. Nova series. Tom XXI. Szerk. Nagy József. Eger 1993 25-42.; Nagy Andor: Egyetemalapítási törekvések a barokk Egerben (1700-1828). In: Az egyetemi tervektől az egyetemmé válásig. A Líceumhoz kötődő egri oktatás története. Szerk. Bartók Béla - Nagy Andor - Makai János. Eger 2019. 37-45. Illetve lásd a jelen kötetben: Verók Attila: Az egyetemépítő Eszterházy Károly. In: Tanulmányok Eszterházy Károly szellemi és épített örökségéről. Szerk. Dinnyés Patrik - Nagy Andor. Eger 2020. 79-94.

6 Antalóczi Lajos: Az Egri Főegyházmegyei Könyvtár története (1793-1996). Eger 2001. 21. 
az egri egyházmegye településein gyüjtött könyvek tartoznak. Eszterházy püspök már az 1767-1769-es egyházlátogatásai során nagy gondot fordított a plébániai könyvtárak felmérésére. Így kerülhettek könyvek Egerbe Csépányfalváról, a gyöngyösi plébánia mintegy 1000 kötete, a kassai domonkosok vagy a bártfai plébánia könyvtárának darabjai, melyek között protestáns szerzők művei is megtalálhatóak voltak. ${ }^{7}$ Itt kell megemlíteni Batthyány Ignác ${ }^{8}$ (1741-1798) egri prépost-kanonok szerepét a gyüjtésben, aki lelkesen segítette püspökét és barátját a könyvek felkutatásában az egyházmegye területén. Számos felbecsülhetetlen értékü kéziratot, ősnyomtatványt, középkori magyar művet vásárolt össze, melyek közül azok, amikre Eszterházy nem tartott igényt, saját gyüjteményébe kerültek. Később erdélyi püspöki kinevezése után e művekből alapította meg 1794-ben Gyulafehérvárott megnyitott püspöki könyvtárát, a Batthyaneumot. A magyarországi gyüjtés harmadik csoportjába azok a könyvek tartoznak, melyeket Büky József? könyvtáros az 1780-as években pesti és pozsonyi könyvkereskedőktől vásárolt, akik a külföldiekhez képest olcsóbban, akár cserekönyvekért is odaadták portékáikat. ${ }^{10}$

A könyvtár gyűjteményének másik részéhez Eszterházy püspök tervszerű beszerzés alapján jutott hozzá. Ebben egyik legnagyobb segítsége Giuseppe Garampi ${ }^{11}$ (1725-1792) püspök volt, akivel még Rómában kötött barátságot. Mikor az olasz fópapot a pápa bécsi nunciussá nevezte ki, 1776-ban meglátogatta Eszterházyt Egerben, ahol volt alkalma megtekinteni a Líceumot és felajánlani segítségét a könyvtár külföldi könyveinek beszerzésére. ${ }^{12}$

Eszterházy sok segítségnyújtást kapott különböző egyetemek oktatóitól is. Az egri Líceum tanárai a püspök kérésére állították össze azon könyvek jegyzékét,

7 Antalóczi L.: Az Egri Főegyházmegyei Könyvtár i. m. 21.

8 Batthyány az egri tartózkodása alatt segített Eszterházy püspöknek a könyvgyüjtésben, aki átengedte neki a kéziratok, kódexek és ősnyomtatványok nagy részét, köztük sok magyar vonatkozású munkát. 1780-ban nevezi ki a pápa erdélyi püspökké Gyulafehérváron, ahol Eszterházy példája nyomán megnyitotta könyvtárát, a Batthyaneumot, csillagvizsgálót építtetett és széleskörű tudományszervező tevékenységet folytatott. Bővebben lásd: Jakó Zsigmond: Batthyány Ignác, a tudós és tudományszervező. In: Erdélyi Múzeum, 53. évf. (1991), 1-4. sz., 76-99., Antalóczi L.: Az Egri Főegyházmegyei Könyvtár i. m. 22. és legújabban: Varjú, Elemér: Biblioteca Batthyaneum la sfârşitul secolului al XIXlea. Bucureşti 2014.

9 Büky József 1781-1805-ig volt a bibliotéka könyvtárosa, Torner Ignác (1736?-1786) után. Már korábban is a Püspöki Iskola tanára volt, fizikát, filozófiát és egyházjogot is tanított, aktívan részt vett a könyvek gyüjtésében. Saját könyveit 1781-ben a könyvtárnak ajándékozta. A könyvek elrendezése „rétnagyságuk és bekötésük minősége szerint” neki köszönhető.

10 Löfler E.: Az Egri Főegyházmegyei Könyvtár. i. m. 11.

11 Eszterházy püspök mellett Garampi Klimó György pécsi püspöknek is segítségére volt könyvtára kialakításában.

12 Leskó József: Garampi József nuncius és egyházmegyénk. In: Egri Egyházmegyei Közlöny 1921/17. 142. 
melyekre az egyes tanulmányi ágaknak szüksége volt. Ezt a katalógust Dobronyai Miklós kanonok terjesztette a püspök elé. ${ }^{13}$ Ezzel egyidejűleg Eszterházy felkérte a budai egyetem tanárait és könyvtárát, hogy készítsék el egyes tudományágak alapvető katalógusait. Ezt a listát Madarassy János (1741-1814) terjesztette Eszterházy elé, aki megbízta azzal, hogy Bécsben csillagászati tanulmányokat végezzen, és az ottani könyvbeszerzésekben legyen segítségére. ${ }^{14}$ Madarassy Garampi nunciussal, Pietro Maria Gazzaniga (1722-1799) és Giuseppe Bertieri (1734-1804) dogmatikaprofesszorokkal, Ferdinand Stögerrel, az egyháztörténet és Karl Scherfferrel (1716-1783) a felső matematika tanárával folytatott tárgyalásokat, ahol a következő vásárlási stratégiát állították össze: először azokat a könyveket szerzik be, melyekre az oktatóknak sürgősen szükségük van, amelyek az oktatáshoz nélkülözhetetlenek. A könyveket lehetőleg nem könyvkereskedőktől vásárolják, mert úgy drágábbak, mintha könyvaukciókon, eladó magánkönyvtárak megvásárlásából vagy első kézből a kiadás helyéről szereznék be a műveket. ${ }^{15}$ Gazzaniga felajánlotta segítségét, valamint olasz és francia kapcsolatait a könyvbeszerzésekhez, illetve saját könyvtárából is kínált fel műveket megvételre. ${ }^{16}$ Garampi a teológiai és történelmi tárgyú munkák felkutatását vállalta magára, és javasolta, hogy Eszterházy bízza meg Jaszvics Bernát volt jezsuita világi papot, hogy a Bécsben zajló könyvlicitációkat figyelje, és alkalomadtán a filozófiai és „összes profán” tárgyú könyvet szerezze meg. Bertieri kiegészítette a meglévő listát néhány újabb, az egyetemi oktatás szempontjából fontos munkával. További segítséget nyújtott a beszerzésekben Agostino Gervasio (1730-1806) Ágoston-rendi tudós szerzetes is. ${ }^{17}$

1781-1785 között Garampi folyamatosan levelezett Eszterházyval és Büky József könyvtárossal a könyvtár érdekében. Könyvügynökeivel az egri könyvtár számára a kívánt dokumentumokat Eszterházy püspök költségén, Európa különböző pontjain, így Németországban, Olaszországban, Spanyolországban, Angliában, Franciaországban és Németalföldön vásároltatta meg. Ezek a könyvek Bécsből hajóval érkeztek Pestre, ahol a szerviták zárdájába lettek elraktározva, míg szekerekkel Egerbe el nem szállították őket. 70 küldemény érkezett így a Líceum könyvtárába. ${ }^{18}$ 1785-ig Garampi segítségével 4336 művet 9323 kötetben sikerült beszerezni az egri püspöki könyvtár számára. Ezekért a munkákért Eszterházy 18131 forintot fizetett. ${ }^{19}$

13 Antalóczi L.: Az Egri Főegyházmegyei Könyvtár i. m. 19.

14 Antalóczi L.: Az Egri Főegyházmegyei Könyvtár i. m. 19; Kelényi B. O.: Eszterházy Károly gróf egri püspök csillagvizsgálójának i. m. 26.

15 Kelényi B. O.: Eszterházy Károly gróf egri püspök csillagvizsgálójának i. m. 29-30.

16 Kelényi B. O.: Eszterházy Károly gróf egri püspök csillagvizsgálójának i. m. 29-30.

17 Löffler E.: Az Egri Főegyházmegyei Könyvtár i. m. 12.

18 Leskó J:: Garampi József nuncius és egyházmegyénk i. m. 142.

19 Antalóczi L.: Az Egri Főegyházmegyei Könyvtár i. m. 20. 
1793. december 28-án nyitotta meg Eszterházy Károly püspök könyvtárát az egri Líceum épületében. Az ország harmadik nyilvános könyvtára ekkor mintegy 16000 kötetet kínálhatott olvasóinak. ${ }^{20}$ Az épület első emeletén, impozáns teremben, Johann Lucas Kracker (1719-1779) és Joseph Zach (1730-1780) Trienti Zsinatot (1545-1563) ábrázoló mennyezetfreskója alatt, faragott tölgyfa állványokon sorakoznak a 16., 17., és 18. század legmodernebb tudományos művei. Batthyány Ignáccal és Patachich Ádámmal (1717-1784) ellentétben azonban Eszterházy nem volt bibliofil könyvgyűjtő, azaz aki a könyveket különleges szépségük, művészi kivitelük, ritkaságuk miatt gyüjti. Az egri püspök célja egy enciklopédikus jellegű egyetemi könyvtár létrehozása volt, mely korának legkeresettebb szakkönyveit tartalmazza az egyetemi oktatás elősegítésére. A beérkező könyvek öszszeírására, rendezésére Eszterházy püspök már 1777-ben könyvtárost nevezett ki. A többi fôpapi könyvtártól eltérően az egri bibliotékához nem társultak egyéb gyüjtemények (pl. numizmatikai gyüjtemény, képtár) az alapításakor.

Eszterházy Károly püspök 1799-es halála után magánkönyvtárát is a líceumi könyvtárra hagyta, így alakult ki az ország egyik legnagyobb könyvgyüjteménye, mely 13879 müvet tartalmazott 20293 kötetben. ${ }^{21}$ Albert Ferenc (1811-1883) könyvtáros 1868-ban készült leírása alapján az Eszterházy-féle állomány a különböző tudományágakra nézve a következőképpen oszlott meg: hittudomány 4148 mủ 5493 kötetben; jogtudomány 2414 mű 2957 kötetben; orvostudomány 514 mű 564 kötetben; történettudomány 2525 mü 4804 kötetben; bölcsészet 1426 mü 1963 kötetben; nyelvészet 2682 mủ 4042 kötetben és vegyes tartalmú 305 mü 654 kötetben. Ezek közül 115 kézirat 130 kötetben, 43 ősnyomtatvány 47 kötetben és „ritkább nyelven írott könyv: 135 munka 187 kötetben”. Albert Ferenc leírása alapján a munkák 30-féle nyelven íródtak, latinul 8971 munka 11711 kötetben, német nyelven 2498 mü 3329 kötetben, franciául 1238 mü 3498 kötetben, olasz nyelven 662 mủ 1149 kötetben, magyarul 224 mủ 251 kötetben, angolul 50 mű 52 kötetben. Ezeken kívül arab, cseh, dalmát, dán, etióp, flamand, gael, görög, gót, héber, izlandi, kaledon, lengyel, oláh, orosz, perzsa, portugál, spanyol, svéd, szerb, szír, török, tót és „válezi” nyelvű munkák is olvashatók az Eszterházy-gyűjteményben. ${ }^{22}$

A könyvtárnak eközben egy olyan különgyüjteménye is kialakult, amely Eszterházy püspök idejében, de már a könyvtár megnyitása elött is létezett: ez a jelen írás fókuszpontjában álló csillagászati gyüjtemény. Ahogy már a bevezetőben olvasható volt, a 18. századi tudományos életben jelentős helyet foglalt el

20 Antalóczi L.: Az Egri Főegyházmegyei Könyvtár i. m. 22.

21 Montedegói Albert Ferencz: Heves és Külső Szolnok törvényesen egyesült vármegyék leírása. Eger 1868. 117.

22 Montedegói A. F: Heves és Külső Szolnok i. m. 118. 
a csillagászat. Ebben az időben Magyarország különböző városaiban sorra épültek a csillagvizsgálók, köztük az egri Líceum obszervatóriuma, mely 1776-ra készült el. 1777-ben, a könyvtár megnyitása előtt már 58 mű 116 kötetben volt található a csillagda különtermében, melyek száma 1799-ben elérte a 75 mü 350 kötetet. ${ }^{23}$ Sajnos a csillagászati munka még a püspök életében elhalt, holott a feltételek adottak voltak hozzá. Eszterházy előbb Balajthy Máté (1732-?), majd Madarassy János egyházmegyei papokat küldte Bécsbe, hogy matematikát és gyakorlati asztronómiát tanuljanak Hell Miksától (1720-1792), a korszak legjelentősebb magyar csillagászától. Hell nemcsak tanácsokkal segítette Eszterházyt a csillagda kialakításában, hanem az ő tervei szerint készült el a torony, a forgatható kupola és a csillagvizsgáló műszaki berendezése is. A gyakorlati munka mellett ő adott javaslatokat a csillagászati gyűjtemény szakkönyveinek kiválasztására is. ${ }^{24}$

\section{A gyưjjemény csillagászati könyvei}

A csillagászati gyüjtemény 1800 előtti köteteinek statisztikai vizsgálatában a megjelenés idejére, helyére, valamint a nyelv szerinti megoszlásra fókuszálunk. A megjelenési idő tekintetében elmondható, hogy a 16. századból összesen 32 csillagászattal kapcsolatos nyomtatott mü került azonosításra. A legkorábbiként regisztrált kiadvány Oronce Fine (1494-1555) francia matematikusnak és kartográfusnak az 1532-ben Párizsban kiadott Protomathesis címü műve. ${ }^{25}$ Emellett több, a században jelentősnek tekinthető munka is megtalálható. A Konrad Celtis (1459-1508) neves humanista által 1501-ben a bécsi egyetemen alapított matematikai-asztronómiai iskolában (Collegium mathematicorum et poetarum) 1504-től Ptolemaiosz kozmográfiáját oktatták. Az innen kikerülő Celtis-tanítványok, majd aztán az ő diákjaik meghatározó szereplőivé váltak a 16. századi német regionális térképészet és kozmográfia művelésének. Itt végzett többek között Peter Bienewitz (Apianus) (1495-1552) reneszánsz tudós, valamint a brassói polihisztor, lutheránus reformátor

23 Antalóczi L.: Az Egri Főegyházmegyei Könyvtár i. m. 26.

24 Kelényi B. O.: Eszterházy Károly gróf egri püspök csillagvizsgálójának. i.m. 22.

25 Fine, Orontius: Protomathesis: opus varium ac scitu non minus utile quam iucundum, nunc primum in lucem foeliciter emissum. Cuius index uniuersalis, in uersa pagina continetur. Parisiis 1532. Jelzete: EFK R. II. 2. A kézirat elkészítésére vonatkozóan a legkorábbi írás azonban Marcus Manilius római költő, asztrológus műve a Krisztus utáni első századból. Lásd: Manilius, Marcus: Astronomicon libri quinque. Recensuit Iosephus Scaliger. Ejusdem Ios[ephi] Scaligeri Commentarius in eosdem libros, et castigationum explicationes. Mamertus Patissonius. Lutetiae 1579. Jelzete: EFK Bb.I ${ }^{\mathrm{xx}} .23$. 


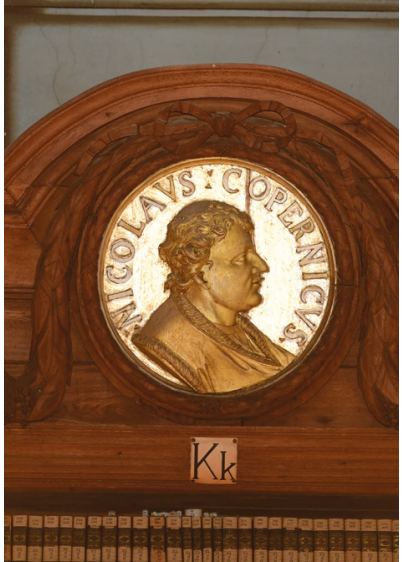

1. kép: Nikolausz

Kopernikusz faragott

dombormüve az egri

Föegyházmegyei Könyvtár

barokk termében

(Szántó György felvétele)
Johannes Honterus (1498-1549) is. Apianusnak a Cosmographicus liber (1524) címủ munkája egészítette ki Ptolemaiosz tanainak elméleti hiányait, ${ }^{26} \mathrm{ami}$ Honterus Rudimenta Cosmographica címü világleírásának közvetlen elődjévé vált. ${ }^{27} \mathrm{Ez}$ utóbbi munka 126 kiadást ért meg a 17. század végéig, és Európaszerte ismertté tette alkotóját. ${ }^{28}$ Eszterházy könyvtárában egy 1558-ban Zürichben megjelent példánya található meg. ${ }^{29}$ Szükséges azonban megemlítenünk, hogy Kopernikusznak a heliocentrikus Naprendszert összefoglaló, az utókor által a 16. századi csillagászat legnagyobb hatású mủvének tartott az Égi pályák rendjéröl (De revolutionibus orbium coelestium, 1543) címü műve nem található meg a gyüjteményben. Ez aligha lehet meglepö, ha hozzávesszük, hogy a kötet 1616-ban a tiltott könyvek listájára került, és ott maradt egészen 1758-ig. A feltáró kutatás tanúságai szerint Eszterházynak ezt követően sem sikerült példányt szerezni belőle. A barokk könyvtártermében azonban egy faragott reliefet szentelt a lengyel csillagásznak.

26 Apianus e korai munkája nem áll rendelkezésre Eszterházy gyűjteményében, de egy későbbi munkája igen. Lásd: Apianus, Petrus: Cosmographia, per Gemmam Phrysium... restituta. Additis de eadem re ipsius Gemma Phry[sii] libellis. Imp. Arnoldi Berckman; absolutum per Aegidium Coppenium. Antverpiae 1539. Jelzete: EFK T.VI.47/1.

27 Török Zsolt Gyöző: Világleírás dióhéjban, avagy bevezetés Honterus későreneszánsz kozmográfiai tankönyvéhez. In: Johannes Honterus: Rudimenta Cosmographica: Grundzüge der Weltbeschreibung (Corona/Kronstadt 1542). Hermannstadt-Bonn 2015. 64.

28 Török Zsolt: Honterus: Rudimenta Cosmographica (1542) - Kozmográfia és/vagy geográfia? In: Honterus Emlékkönyv: Emlékülés és kiállítás Johannes Honterus halálának 450. évfordulója alkalmából az Országos Széchényi Könyvtárban, 1999. = Honterus-Festschrift: Wissenschaftlich Tagung und Austellung zum 450. jährigen Todestage von Johannes Honterus in der Ungarischen Széchényi Nationalbibliothek, 1999. Bp. 2001. 57. Az erdélyi szász tudós munkájának könyvtörténeti különlegességeiről lásd Verók Attila ismertetőjét az alábbi műről: Johannes Honterus: Rudimenta Cosmographica. Grundzüge der Weltbeschreibung (Corona/Kronstadt 1542). Ins Deutsche, Rumänische und Ungarische übersetzte und kommentierte Faksimile-Ausgabe. Hg. Offner, Robert - Roth, Harald - Şindilariu, Thomas - Wien, Ulrich Andreas. Hermannstadt - Bonn 2015. 364, [2]. In: Magyar Könyvszemle. Könyv- és sajtótörténeti folyóirat, 132. évf. (2016) 1. sz., 118-124. és uö.: Luther és Honterus emlékezete az erdélyi szászoknál a kora újkorban. In: A reformáció emlékezete. Protestáns és katolikus értelmezések a 16-18. században. Szerk. Fazakas Gergely Tamás - Imre Mihály. Debrecen 2018. 75. (Loci memoriae Hungaricae; 7).

29 Honterus, Johannes: Rudimentorum cosmographicorum... libri 3. cum tabellis geographicis elegantissimis. De variarum rerum nomenclaturis per classes liber 1. Apud Friscgouerum. Tiguri 1558. Jelzete: EFK Cs 4.030/3. 
Hiányoznak azonban Tycho Brahe (1546-1601) dán csillagásznak művei is, akinek a munkássága szintén rendkívül jelentős az új világkép tudományos bizonyításának folyamatában. Ugyanakkor Erasmus Reinholdnak (1511-1553) a csillagászati táblázatai, amelyeket Kopernikusznak a műve alapján készített, rendelkezésre állnak. ${ }^{30}$ Bár Reinhold munkásságában nem fedezhetőek fel Kopernikusznak a tanai, mégis azok terjedését ezen táblázatok is segítették. ${ }^{31}$

A kollekció 16. századi részének szerzői között túlnyomórészt a német birodalmi városok csillagászainak könyveit fedezhetjük fel, úgymint Johannes Stöffler (14521531), Johannes Schöner (1477-1547), Sebastian Theodoricus (1520-1574), Caspar Peucer (1525-1602), Christophoprus Clavius (1538-1612) vagy Michael Maestlin (1550-1631) német csillagászok és matematikusok munkáit. Mellettük kivételként előfordul még egy francia és egy itáliai tudós munkája. ${ }^{32}$

A 17. század legjelentősebb csillagászai között tartja számon a tudománytörténet Galileo Galilei (1564-1642) itáliai fizikust, matematikust és csillagászt. Az ő nevéhez füződik a Jupiter és a Mars holdjainak felfedezése és részletes megfigyelése; ő fedezte fel a napfoltokat, a Nap forgását és a Hold krátereit. Ezen kívül kísérleteket végzett a gravitáció és a dinamika törvényeinek megismerésére is. Megfigyeléseinek eredeti kiadásai közül - Kopernikuszhoz hasonlóan - egyik sem ismeretes Eszterházy csillagászati gyűjteményében (bizonyosan az indexre tétele miatt). Egy 1699-ben megjelent műve azonban kivonatosan összefoglalja az 1632-ben kiadott Dialogo című nagyhatású művét. ${ }^{33}$ Érdemes megemlíteni azonban azt is, hogy Eszterházy nemcsak Kopernikusznak, hanem Galileinek is emléket állított a könyvtárában egy relief által.

Hogy Johannes Kepler (1571-1630) német matematikus, csillagász műveinek megléte ritkaságnak számít a legtöbb csillagászati gyüjteményben. ${ }^{34} \mathrm{~A}$ jelentősebb munkái közül az első kettő (Mysterium

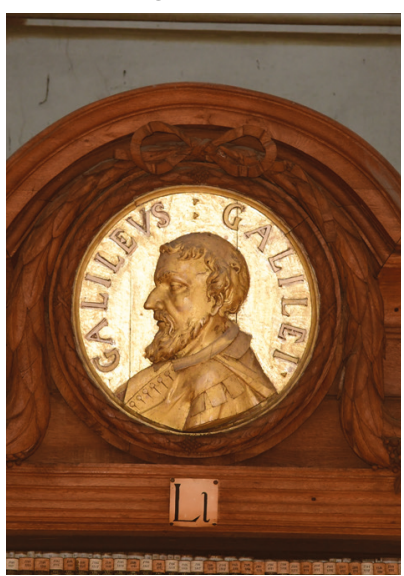

2. kép: Galileo Galilei faragott dombormüve az egri Föegyházmegyei Könyvtár barokk termében (Szántó György felvétele)

30 Reinhold, Erasmus: Prutenciae tabulae coelestium motuum. Apud Gruppenbach. Tubingae 15711573. Jelzete: EFK Cs 2.030.

31 Mészáros Ernö: A természettudományok rövid története. Bp. 2011. 61.

32 A már említett Oronce Finé, illetve Giovanni Nicolò Doglioni (1548-1629) velencei matematikus.

33 Galilaeus, Galilaei: Systema cosmicum, in qou dialogis IV de duobis maximus Munda Systematibus, Ptolemaico et Copernicano... disseritur. Ejusdem tractatus De motu. F. Haaring D. Severinus. Lugduni Batavorum 1699. Jelzete: EFK Oo VII. 33/1.

34 Lásd: Surányi I.: Az Egri Főegyházmegyei Könyvtár könyvritkaságai i. m. 143. 
cosmographicum, 1596; Astronomia nova, 1609), amelyben a gravitációs hatás megsejtését, másfelől a bolygómozgások első két törvényét írja le, Eszterházy gyűjteményéből is hiányzik. Ez az állítás azonban annyi kiegészítésre szorul, hogy Kepler első fő művének tanítása megtalálható egy másik, 1621-es csillagászati értekezésben. ${ }^{35}$ Ezek mellett pedig megtalálható Keplernek a bolygómozgások 3. törvényét leíró Világok harmóniája (Harmonices mundi, 1619) címü munkája is - első kiadásban. ${ }^{36}$ Továbbá Kepler maga is úgy vélte, hogy a heliocentrikus világképpel pontosabb megfigyeléseket lehet tenni, ezért a csillagászati táblázatokat ő maga is tovább kívánta javítani. Éppen ezért szintén jelentős műveként tartjuk számon az 1627-ben Prágában megjelentetett és Habsburg Rudolf (ur. 1576-1612) császárnak ajánlott asztronómiai táblázatát (Tabulae Rudolphinae) is. Eszterházy könyvtárában ez nem, de az ugyanebben az évben Ulmban megjelent változata viszont már megtalálható. ${ }^{37}$ Itt jegyezzük meg, hogy Eszterházynak sikerült szert tennie Keplernek a kopernikuszi csillagászatot kivonatoló kötetére is, amivel a lengyel csillagász tanai szintén megtalálhatók voltak a gyüjteményében. ${ }^{38}$

Kepler mellett több jelentős 16-17. századi csillagász munkája is megtalálható Egerben. Ezek felsorolása helyett (amelyet a bevezetőben említett távlati munkánkban tételesen is be kívánunk mutatni) a 17. századi könyvek megjelenési helyeit említjük meg. Ezek körében szintén a német városok túlsúlya jelenik meg (Frankfurt am Main, Ingolstadt, Klagenfurt, Lipcse, Nürnberg, Ulm, Wittenberg, Würzburg stb.), amelyet immár több németalföldi (Alkmaar, Amsterdam, Hága, Leiden), itáliai (Bologna, Bracciano), osztrák (Bécs, Linz), lengyel (Gdańsk), francia (Párizs) és magyar (Nagyszombat) város is színesít. ${ }^{39}$

Ha viszont a kora újkor három évszázadának kollekcióját kívánjuk egymással összehasonlítani, akkor azt mondhatjuk, hogy a 17. században közreadott művek száma csak kis mértékben haladja meg az előző évszázadét (47 csillagászati mű

35 Keplerus, Johannes: Prodromus dissertationum cosmographicarum, continens Mysterium cosmographicum de admirabili proportione orbium coelestium... Addita est erudita Narratio M. Georgii Joachimi Rhetici, de Libris resolutionum... Nicolai Copernici. Item eisudem Joannis Kepleri pro auo opere harmonices mundi Apologia. Sumpt. Tampachii. Francofurti 1621. Jelzete: EFK Cs 0.010/1.

36 Keplerus, Johannes: Harmonices mundi libri 5. Sumpt. Tampachii. Lincii Austriae 1619. Jelzete: EFK Cs 0.010/2.

37 Keplerus, Johannes: Tabulae Rudophinae, quibus astronomicae scientiae ... restauratio continentur; a Tychine ... Braheorum .. Familia ... primum ... concepta ... perfecit, absolvit Johannes Keplerus. Ulmae 1627. Jelzete: EFK Cs 0.006.

38 Keplerus, Johannes: Epitome astronomiae Copernicanae usitate forma questionum et responsionum conscripta, inque 7. libros digesta, quorum tres... De doctrina sphaerica... Imp. Schönwetter Francofurti 1635. Jelzete: EFK Cs 4.025.

39 A gyüjtemény 17. századi csillagászati kollekciójának egyetlen magyar származású asztronómusának műve a jezsuita szerzetes, Szentiványi Márton (1633-1705) hittudós munkája, 1689-ből. Lásd: Szentiványi Márton: Curiosiora et selectiora variarum scientiarum miscellanea: In tres partes divisa. Decas prima. Typ. Academicis. Tyrnaviae 1689. Jelzete: EFK Uu.IV.68. 
került regisztrálásra). A 18. században megjelent csillagászati művek száma azonban jelentős fölényt mutat a 191 regisztrált kiadvány értékével. Az alábbi diagram az imént elmondottakat foglalja össze.

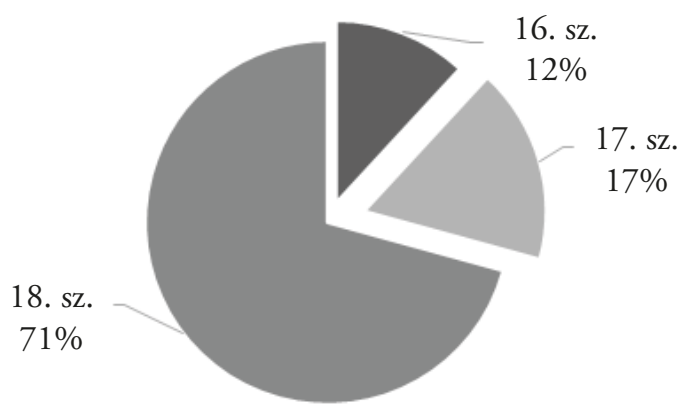

1. ábra: A csillagászati könyvek megjelenési idö szerinti megoszlása

Az újkori természettudomány legnagyobb alakjaként Isaac Newtont (16421727) tiszteli a tudománytörténet. Ő valósította meg a tudósok évszázados álmát, a természet matematikai leírását. Végleg „széttörte” az arisztoteliánus gondolkodás bilincseit, bebizonyítva, hogy az égi és a földi mozgásokat ugyanazok a törvények irányítják, vagyis csak egyetlen fizika létezik. ${ }^{40} \mathrm{~A}$ korszak másik jelentős csillagászának, Edmund Halleynek (1656-1742) köszönhetö, hogy 1686-ban - Halley anyagi támogatásával - megjelenhetett Newton legjelentősebb műve: A természetfilozófia matematikai elvei (Philosophiae Naturalis Principia Mathematica). A kötet Newton több más mủvével együtt megtalálható Eszterházy gyüjteményében. ${ }^{41}$

Halley ebben az időben csillagászati obszervatóriumot alapított Szent Ilona szigetén (Saint Helena), ahol a déli félteke csillagképeinek katalógusát készítette el. Ugyanitt elsőként figyelte meg a csillagok úgynevezett saját mozgását. Már ekkor felvetette, hogy a Vénusz-átvonulást fel lehetne használni a Naprendszer méreteinek meghatározására. ${ }^{42}$ Newton mozgástörvényeit Halley az égitestek mozgásának elemzésére alkalmazta. Ennek alapján számította ki az 1682. évi üstökös

40 Ujfaludi László: Helyünk az univerzumban - A csillagászat rövid története: I. rész. Az Eszterházy Károly Főiskola tudományos közleményei (Új sorozat 38-39. köt.). Tanulmányok a környezettudomány területéről In: Acta Academiae Agriensis. Sectio Pericemonologica (Tomus 6-7.). Eger 2012. 69.

41 A könyvtárban őrzött Newton művek: Newton, Isaac: Opuscula mathematica, philosophica, et philologica Coll. Recensuit Joh[annes] Castillioneus 1-3. Tom. M. M. Bousquet. Lausanne - Genevae 1744. Jelzete: EFK I.VI.30-32; Newton, Isaac: Philosophiae naturalis principia mathematica: 1-3. Tom. 2. ed. emendatior Coloniae Allobrogum. Cl. A. Philibert, 1760. Jelzete: EFK H. VI. 19-21.; Newton, Isaac: Opera quae extant omnia : 1-2. T. Londini 1779. Jelzete: EFK S. IV. 13-14.

42 Herrmann, Dieter B.: Az égbolt felfedezői. Bp. 1981. 110-114. 
pályáját, és megjósolta annak 1758. évi visszatérését. ${ }^{43}$ Sajnálatosan Halleynek egyetlen munkája sem található meg a gyűjteményben.

A csillagászattörténet egyik legnagyobb adatgyüjtőjének nevezik Nicolas de Lacaille abbé (1713-1762) francia csillagászt, aki a déli égbolt egyik legjelentősebb megfigyelője volt, hosszú ideig a Jóreménység-fokán végzett megfigyeléseket, ahol több mint 10 ezer csillag katalógusát állította össze (ez volt az addigi legnagyobb csillagkatalógus). ${ }^{44} \mathrm{~A}$ fontosabb művei közül egyet említhetünk meg az egri könyvtárban, ${ }^{45}$ a többi tudományos megfigyelése, beleértve a csillagkatalógusát is, hiányzó példányok a gyüjteményben.

A század nagy vállalkozása a Vénusz-átvonulás megfigyelése volt. A Vénusz bolygó napkorong előtti átvonulásának pontos észlelése lehetőséget ad a Nap-Föld távolság meghatározására. Kepler 3. törvénye összefüggést ad a bolygók keringési ideje és a Naptól mért közepes távolságuk között, de ez csak arányszámokat jelent, a pontos távolságokat nem adta meg. A Nap-Föld távolság ismerete és a Kepler-törvény alapján viszont már valamennyi bolygó távolságát ki lehetett számítani, vagyis ismertté váltak a Naprendszer valódi méretei. Szent Ilona-szigeti obszervatóriumából Halley már 1677-ben megfigyelte a Vénusz-átvonulást, de nem volt elégedett a mérés pontosságával, ezért már akkor javasolta, hogy a következő átvonulást 1761-ben nagyobb felkészültséggel, pontosabb mérésekkel végezzék el. 1761-ben ennek érdekében jött létre az első nagy nemzetközi tudományos együttműködés. Számos kutatócsoport indult a világ különböző tájaira, hogy a pontos mérést elvégezzék. A nemzetközi összefogás sem hozott azonban kielégítő eredményt. Ezért már ekkor elkezdték a felkészülést a következő, 1769. évi Vénusz-átvonulás megfigyelésére. Lalande, korának egyik legjelentősebb csillagásza, 1764-ben nagy érdeklődést keltő tanulmányt írt a következő, 1769. évi Vénusz-átvonulás megfigyelésének lehetőségeiről. Nem kis mértékben ennek köszönhető, hogy 1769-ben újabb nagy nemzetközi együttműködés jött létre a cél érdekében. Az egri csillagászati szakrészlegben nemcsak az ez utóbbi (1764-es) munka van meg, ${ }^{46}$ hanem munkásságának többi, jelentősebb írása is. ${ }^{47}$

43 Az üstökös valóban visszatért 1758-ban. Halley akkor már nem élt, de az üstököst az ő emlékére azóta Halley-üstökösnek nevezik. Legutóbbi két visszatérése 1910-ben és 1986-ban volt.

44 Ezen kívül hajóútjain a tengeren történő helymeghatározással foglalkozott. Napfogyatkozás-táblázatot is készített, ebben több száz évre előre jelezte a várható napfogyatkozásokat.

45 Lacaille, Nicolas Louis de: Lecons élémentaires d'astronomie géometrique et physique. Augm... notes par M. de la Lande. 4. ed. Paris 1780. Jelzete: EFK Cs 2.036/1.

46 Lalande, Joseph Jerome: Explication de la figure du passage de Venus sur le disque du soleil, qui s'observera le 3 juin 1769... Impr. Herissant. Paris 1764. Jelzete: EFK Cs 0.021/2.

47 Az alábbi művei találhatóak meg az egri gyüjteményben: Lalande, Joseph Jerome: Expositiom du calcul astronomique. Impr. Roxale. Paris 1762. Jelzete: EFK Cs 4.039.; Lalande, Joseph Jerome: Abrégé d'astronomie. Paris 1774. Jelzete: EFK I.VII.14. (illetve ugyanebben az évben egy újabb kiadása is: Jelzete: EFK Cs 2.037); Lalande, Joseph Jerome: Memoire sur le passage de Venus ob. Paris 1772. Jelzete: EFK Cs 0.021/1.; Lalande, Joseph Jerome: Astronomie. 3. éd. Tom. 1-3. Paris 1792. Jelzete: EFK Cs 0.028-030. 
Hell Miksa (1720-1792) és Sajnovics János (1738-1795) magyarországi csillagászok szintén részt vettek a nemzetközi együttműködésben. ${ }^{48}$ VII. Keresztély (Christian) (1749-1808) dán király támogatásával a Lappföldről, Vardø (Vardö) szigetről figyelték meg a Vénusz-átvonulást, és végeztek igen pontos méréseket 1769. június 3-án. Más kutatócsoportok Kanadából, Szentpétervárról, New Englandból (jelenleg: USA) figyelték meg a nevezetes eseményt. James Cook (1728-1779) kapitány Tahiti szigetéről végzett megfigyelést, majd onnan továbbhajózva első európaiként ismerte meg (fedezte fel) Ausztráliát és Új-Zélandot. Hell Miksa mérései igen pontos értéket adtak a NapFöld távolságra (150 millió km), és ennek nyomán nemzetközileg elismert csillagász lett. ${ }^{49}$ Hell a számításait az Ephemerides astronomicae évkönyv 1770-es különszámában jelentette meg - saját cím alatt -, amely nem hiányzik az egri csillagásztorony könyvtárából sem. ${ }^{50}$ Hell a következő években számos magyar csillagászati obszervatóriumot alapított, és ezzel úttörő jelentőségű lépést tett a magyarországi csillagászat fejlesztésében. Számos munkája közül jó néhány megtalálható Egerben. ${ }^{51}$

William Herschel (1738-1822) szász udvari muzsikusként vándorolt át Angliába, és ott vált nemzetközi hírű csillagásszá. Londonban már királyi csillagászként óriás távcsöveket épített, ezekkel végezte megfigyeléseit. 1781-ben felfedezte az Uránusz bolygót (az első olyan bolygó, amely szabad szemmel nem látható). Később felfedezte az Uránusz és a Szaturnusz több holdját. ${ }^{52}$ Herschel jelentős müvei közül egyet regisztráltunk Eszterházy egykori könyvtárában. ${ }^{53}$

$48 \mathrm{Az}$ expedícióról és sok egyéb csillagászati vonatkozásról is olvashatunk nemzetközi közegbe helyezve az alábbi két monográfiában: Pärr, Nora: Maximilian Hell und sein wissenschaftliches Umfeld im Wien des 18. Jahrhunderts. Nordhausen, Bautz, 2013. (Religionsgeschichte der frühen Neuzeit; 14) és Aspaas, Per Pippin - Kontler, László: Maximilian Hell (1720-92) and the Ends of Jesuit Science in Enlightenment Europe. Leiden-Boston 2020. (Jesuit Studies; 27)

49 Társa, Sajnovics János nagy érdeme, hogy felismerte a magyar és a lapp nyelv hasonlóságát és ezzel elindította a finnugor nyelvészet tudományát.

50 Hell, Maximilian: Observatio transitus Veneris ante discum Solis die 3. Junii Anno 1769. Wardoehusii facta, et societati. Reg. Scientiarum Hafniensis die 24 novembris 1769 praelecta. Vondobonae 1770. Jelzete: EFK Cs.3.035. Lásd még: Surányi I.: Az egri Főegyházmegyei Könyvtár könyvritkaságai i.m. 151.

51 Hell további munkái az egri Főegyházmegyei Könyvtárban: Hell, Maximilian: Adjumentum memoriae manuale chronolog, genealogico-historicum... Viennae 1750. Jelzete: EFK Gg. I. 53.; Hell, Maximilian: Ephemerides astronomicae anni 1782. Viennae 1781. Jelzete EFK G.III.44; Hell, Maximilian: Monumenta, aere perenniora, inter astra ponenda... proposita, et dedicata. Viennae 1789. Jelzete EFK: Cs 3.006.; Hell, Maximilian: Chronologisch-genealogischhistorisches Handbuch zum des Gedächtnisses. Aus dem Lateinischen übersetzet... und bis auf das Jahr 1797 fortgesetzt von Geusau Anton. Wien 1797. Jelzete: EFK Kk.Ix.63.

52 Emellett ő volt a spektroszkópiai megfigyelések úttörője is: prizmákkal figyelte meg a csillagok fényének spektrumát, módszerét később Robert Bunsen (1811-1899) és Joseph von Fraunhofer (1787-1826) fejlesztette tovább. Felfedezte a láthatatlan infravörös (hő)sugárzást és ezzel megtette az első lépést a teljes elektromágneses spektrum felfedezése felé.

53 Herschel, William: On the parallax of the fixed starts: catalogue of the parallax; description of a lamp-micrometer; and investigation of magnifying powers. London 1782. Jelzete: EFK Cs 4.121/4. 
Charles Messier (1730-1817) híres katalógusát 1784-ben adta ki Catalogue des Nébuleuses \& des amas d'Étoiles címmel. A katalógus 110, akkor még kevéssé ismert mélyégobjektum leírását és rajzát tartalmazta. A Messier-katalógus máig a referenciaművek közé tartozik, az M1-M110 hivatkozás a csillagászati közleményekben jelenleg is az egyik legfontosabb hivatkozásnak számít az égi jelenségek helymeghatározásában. Messier csillagászati életműve más szempontból is jelentős: 13 üstököst fedezett fel. Sajnálatosan azonban egyetlen példány sem ismert Eszterházy gyüjteményében tőle.

Immanuel Kant (1724-1804) 1755-ben jelentette meg a világegyetem keletkezéséről szóló tanulmányát Allgemeine Naturgeschichte und Theorie des Himmels címmel, amely a Newton-féle gravitációs elmélet alapján írta le az univerzum fejlödését. Ezen munkája nem került regisztrálásra Eszterházy gyűjteményében - bár számos egyéb írása megtalálható. ${ }^{54}$

Pierre Simon Laplace (1749-1827) 1796-ban megjelent mủvében a Newtonelmélet alapján pontos matematikai módszerek alkalmazásával alátámasztva ismerteti kozmogóniai elméletét. Tanai azonban már csak Eszterházy halála után kerülhettek be az egri könyvtárba - egy német nyelvü fordításban. ${ }^{55}$

A fent említett művek csupán a tudománytörténet legjelentősebb fordulatai alapján kerültek válogatásra. Hozzá kell tennünk, hogy ezeken kívül még számos 18. századi csillagászati munka előfordul a gyüjteményben, aminek felsorolása szétfeszítené a jelen dolgozat kereteit. Átfogó bemutatásunknál maradva azonban szükségét érezzük diagramon bemutatni a könyvek nyelv szerinti megoszlását.

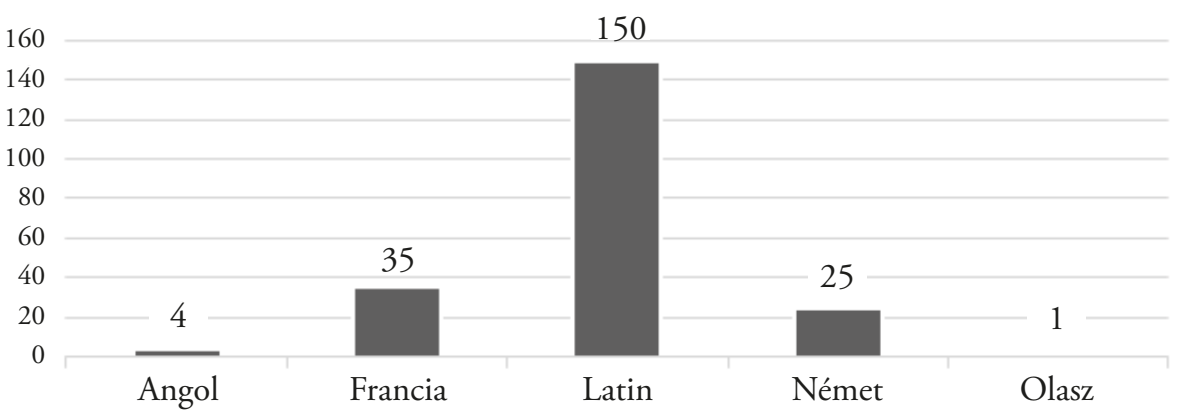

2. ábra: A csillagászati könyvek nyelv szerinti megoszlása

54 A természettudományi munkáit tekintve az alábbi kötet ismert az egri gyűjteményben: Kant, Immanuel: Metaphysische Anfangsgründe der Naturwissenschaft. Riga 1786. Jelzete: EFK UU. X. 84. Ugyanennek a műnek egy 1796-os kiadása is megtalálható: jelzete: EFK T. III. 112.

55 Laplace, Pierre Simon de: Mechanik des Himmels. Aus dem Französischen übers ... von J. C. Burckhardt. Berlin 1800-1802. Jelzete: EFK Cs 0.014-015. 
A fenti diagramon jól látható, hogy az 1800 előtti csillagászati munkák jelentős része latin nyelven (150 mü) található meg a gyüjteményben. Ezt követi a francia (35 mü), a német ( 25 mü), az angol ( 4 mü) és egy olasz nyelvű alkotás.

Ha azonban a kiadványokat nyomdahely szerint figyeljük meg, akkor Párizs emelkedik ki a többihez képest 31 kötettel. Ezt követi Bécs, Amsterdam és Wittenberg, majd további német, itáliai, németalföldi, magyar és angol városok nevei.

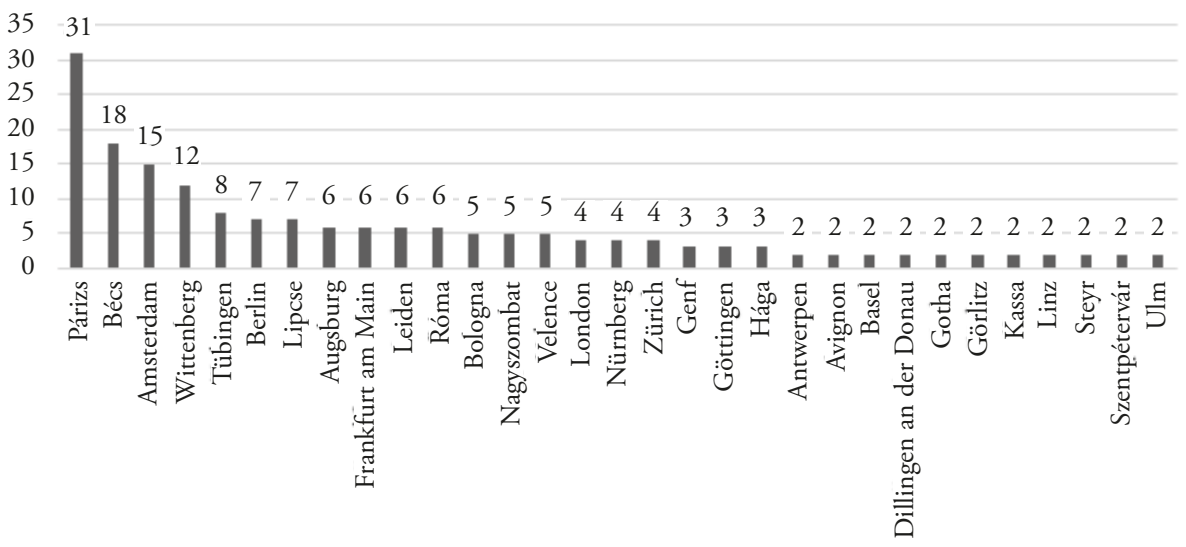

3. ábra: A kiadványok nyomdahely szerinti megoszlása

A diagramon csak az egynél többször előforduló nyomdahelyeket tüntettük föl. Ezen kívül még további 25 településnév került regisztrálásra egy-egy kiadvánnyal, illetve még további 8 kötet esetében nem ismert a megjelenés helye.

\section{Összegzés}

A jelen tanulmányban Eszterházy Károly egri püspök 1800 elött megjelent csillagászati könyvanyagát mutattuk be könyvtár- és tudománytörténeti szempontból. Összefoglalóan azt mondhatjuk, hogy Eszterházy a 16-18. század minden jelentős kiadványát igyekezett beszerezni, amivel teljes körű asztronómiai képzettségre tehettek (volna) szert az egri egyetemen tanuló hallgatók. Láttuk, hogy ha nem is tudta minden fontos kiadvány eredeti (első) változatát beszerezni, akkor gyakran későbbi kiadásokkal, összefoglaló munkákkal pótolta azok hiányát. Némely esetben azonban a hiányosságokra is fény derült, de azok is inkább a 18. század második felére, harmadik harmadára eső művek. A könyvtár későbbi (teljeskörü) csillagászati kiadványainak feltáró munkájával azonban árnyalhatóvá válhat még ezen hiányosság is. 
Itt említjük meg, hogy az egri Főegyházmegyei Könyvtár gyűjteménye ma mintegy 175000 kötet számlál. Már eddig is sok lehetőséget kínált a könyvészeti, irodalomtörténeti, illetve egyéb történeti kutatások számára, de az állomány nagysága és kora révén több, eddig kiaknázatlan forrást is biztosít azoknak, akik az egyes kötetek provenienciája, a gyűjteményegységek kora vagy azok összetétele iránt érdeklődnek. A könyvtár történetében két időszak volt, amikor tervszerü állománygyarapítás keretében bővítették: mégpedig a 20. század utolsó harmadától napjainkig, valamint az alapítás időszaka - amely jelen írás fókuszában állt. Az alapító halálával kialakult Eszterházy-gyüjtemény bőséges feladatokkal látja el az intézményben dolgozó könyvtárosokat, valamint a kutatókat, akiknek feladata ellenőrizni, hogy a 18. századi állomány minden egyes darabja fellelhetö-e ma is a könyvtárban (illetve mit lehet tudni a hiányzó példányokról). További munkát jelentő feladat összevetni az egykor megvásárolt könyveket a gyüjtés során különböző egyetemek profeszszoraitól kapott listákkal, felmérni, hogy a hagyatékok, ajándékok milyen összetételűek, mely művek találhatóak meg belőlük a jelenlegi állományban. Könyvészeti szempontból pedig szintén fontos kutatási feladat a másodlagos kötések feltárása, beazonosítása is. A gyűjtemény témakörönkénti, tudományágak szerinti elemzése és vizsgálata is hiánypótló, időszerű feladat. A gyüjtemény tehát még nagyon sokáig jelent elvégzendő feladatot a kutatóinak. Tanulmányunk is ezen hiányosságok felszámolása felé kívánt lépést tenni és igyekszik felhívni a figyelmet a további elvégzendő feladatokra. Éppen ezért az írásunk célja az is, hogy ráirányítsa a figyelmet a püspöki könyvtár további szakrészlegeinek hasonló vizsgálatára. ${ }^{56}$ Ezen feltáró munkák elvégzésével lehet esélyünk ugyanis arra, hogy még pontosabb ismeretekkel rendelkezzünk Eszterházynak az egyetemi képzéséhez vásárolt könyvtáráról (illetve a gyűjtemény későbbi anyagáról). Ezen eredmények nyújtanak lehetőséget végül arra is, hogy minden korábbinál alaposabb összehasonlításokat végezhessünk az egri püspök és korának hazai és európai könyvgyüjtő személyiségeivel kapcsolatban is.

56 Ebből a szempontból kiemelendő Kiss Gábornak a jelen tanulmánykötetben megjelenő írása is. Lásd: Kiss Gábor: Az egri Főegyházmegyei Könyvtár egyházjogi állományának vizsgálata a könyvtár alapításától 1899-ig. In: Tanulmányok Eszterházy Károly i. m. Szerk. Dinnyés Patrik - Nagy Andor. Eger 2020. 113-126. 


\section{Astronomische Bücher der Bibliothek von dem Erlauer Bischof Károly Eszterházy}

Die Autoren der Studie untersuchen die Zusammensetzung der astronomischen Sammlung der Bibliothek von Károly Eszterházy. Beim Aufbau der Universität war eine der wichtigsten Bemühungen des Bischofs, die Astronomie auf einem hohen Bildungsniveau zu lehren. Durch seine umfangreichen Kontakte sorgte er auch für die Beschaffung entsprechender Fachbücher. Wir wissen jedoch auch heute noch wenig darüber, welche Veröffentlichungen der Bischof von Erlau für seine zukünftige Universität kaufte. Obwohl der Bibliothekskatalog bereits fertiggestellt ist, fand die analytische Präsentation davon noch nicht statt. Der vorliegende Beitrag beabsichtigt, bezüglich der astronomischen Bücher diese Lücke zu schließen, indem er versucht, nach Erscheinungsort, -zeit, thematischer und sprachlicher Verteilung der Veröffentlichungen über die Sammlung ein umfassendes Bild zu liefern. Die vorgestellten Ergebnisse bieten auch die Möglichkeit dazu, den Bischof von Erlau sowohl mit den einheimischen als auch mit den ausländischen Büchersammlern zu vergleichen.

\section{Astronomické knihy v knižnici jágerského biskupa Karola Eszterházyho}

Autori štúdie sa venovali predmetnej zbierke astronomickej literatúry z formálnych (bibliografických) hladísk. V rámci snahy budovania jágerskej univerzity malo kvalitné vyučovanie astronómie nenahraditel'né miesto. Na zriadenie tunajšej hvezdárne preto biskup oslovil jedného z najvýznamnejších astronómov doby a vd’aka svojim širokým kontaktom zároveň zabezpečil aj potrebnú kvalitnú literatúru. Presne ktoré knihy však nakúpil na plánovanú univerzitu, o tom vieme už pomenej. Lístkový katalóg tejto knižnice je už síce na svete, no jeho analýza sa dodnes nevykonala. Štúdia sa snaží odstránit tento nedostatok predstavením kolekcie prostredníctvom údajov vypovedajúcich o mieste, čase, tematike a jazyku knižných jednotiek. Zároveň chce poukázat na možnosti pokračovania v tejto práci so zretel'om na ostatné odborné kolekcie knižnice spomínaného biskupa. Výsledky pomôžu aj komparáciám s knižnými kolekciami, resp. s osobnostami dobovej domácej i európskej knižnej zberatel'skej činnosti. 